JPdK Volume 3 Nomor 2 Tahun 2021 Halaman 157-161 JURNAL PENDIDIKAN dan KONSELING Research \& Learning in Primary Education

\title{
Konseling Human Trafficking Di Sambas
}

\author{
Rifqi Muhammad $\bowtie$ \\ Institut Agama Islam Sultan Muhammad Syafiuddin Sambas \\ Email: ananda.rhifqie@gmail.com
}

\begin{abstract}
Abstrak
Penelitian ini dilatar belakangi adanya penanganan kasus korban human trafficking oleh Kemenpppa Kabupaten Sambas. Tujuan penelitian untuk 1) mendeskripsikan alur penanganan kasus human trafficking; 2) mendeskripsikan pelaksanaan bimbingan konseling terhadap korban kasus human trafficking; 3) mendeskripsikan hambatan penanganan kasus korban human trafficking di Kemenpppa Kabupaten Sambas. Prosedur penelitian ini menggunakan kualitatif deskriptif. Penelitian ini dilakukan di Kemenpppa Kabupaten Sambas, Kalimantan Barat, Indonesia. Hasil penelitian 1) alur penanganan terdiri dari Pencegahan (Penyuluhan kepada masyarakat, konseling, pembentukan peraturan perundang-undangan); Penanganan (Pendampingan dan bantuan hukum, koordinasi dengan instansi terkait, pelayanan kesehatan); dan Pemulihan (Bimbingan mental spiritual, bimbingan fisik, bimbingan sosial); 2) bimbingan konseling dilakukan melalui program PULPUS yaitu diberikan sesuai dengan kebutuhan korban perseorangan; 3) Hambatan terjadi karena a) korban dan keluarga korban biasanya bukan menganggap apa yang dialami itu merupakan sebuah kejadian human trafficking; b) ada penerima modal usaha yang tidak menggunakan modal sesuai tujuan.
\end{abstract}

Kata Kunci: Konseling; Human Trafficking; Sambas

\begin{abstract}
This research is motivated by the handling of cases of victims of human trafficking by the Kemenpppa of Sambas Regency. The research objectives are to 1) describe the flow of handling human trafficking cases; 2) describe the implementation of counseling guidance for victims of human trafficking cases; 3) describe the obstacles to handling cases of victims of human trafficking at Kemenpppa, Sambas Regency. Prosedur penelitian ini menggunakan kualitatif deskriptif. This research was conducted at Kemenpppa Sambas Regency, West Kalimantan, Indonesia. The results of the study 1) the flow of handling consists of prevention (examination to the community, counseling, formation of laws and regulations); Handling (Assistance and legal assistance, coordination with relevant agencies, health services); and Recovery (mental spiritual guidance, physical guidance, social guidance); 2) counseling guidance is carried out through the PULPUS program, which is given according to the needs of individual victims; 3) Barriers occur because a) victims and their families usually do not consider what they have experienced as an incident of human trafficking; $b$ ) there are business capital recipients who do not use the capital according to the purpose.
\end{abstract}

Keywords: Counseling; Human trafficking; Sambas

\section{PENDAHULUAN}

Fenomena Tindak Pidana Perdagangan Orang (TPPO) yang sering ditemukan dalam persidangan, sebagian besar korban TPPO untuk tujuan eksploitasi seksual dan bekerja pada tempat-tempat kasar dengan upah rendah, seperti di perkebunan, buruh, dan pekerja rumah tangga. Di antara faktor yang menyebabkan terjadinya TPPO, antara lain yaitu kebiasaan "merantau"atau "ngenger" untuk memperbaiki nasib; kemiskinan dan tingkat pendidikan rendah; tradisi mengawinkan anak usia muda; gaya hidup kota yang konsumtif; kebiasaan menganggap pelacuran sebagai hal yang lumrah; bisnis buruh migran berkembang menjadi industri yang sangat menguntungkan; semakin meningkatnya kejahatan terorganisir; diskriminasi dan persoalan gender; dan memenuhi kebutuhan narkoba (Kemenpppa, 2018)

Kasus penjualan manusia atau sering disebut dengan human trafficking merupakan kasus serius dan sering terjadi di Indonesia. Hal inilah yang menjadi perhatian pemerintah untuk menekan angka perdagangan orang. Sambas merupakan salah satu daerah yang rawan terjadi perdagangan orang, 
karena secara geografis, letak Sambas yang berbatasan langsung dengan Malaysia dan Brunei Darussalam.

Rentannya daerah kabupaten Sambas mengalami kasus human trafficking karena letaknya yang berbatasan langsung dengan negara tetangga. Khusus di Kabupaten Sambas sudah ada (Peraturan Daerah Kabupaten Sambas No. 3 Tahun 2015 Tentang Pencegahan Dan Penanganan Perdagangan Orang, 2015). Pada Bab IV pasal 6, menerangkan bahwa pencegahan perdagangan orang dapat dilakukan melalui: 1) Pemetaan permasalahan perdagangan orang; 2) Perencanaan program dan pengalokasian anggaran pencegahan dan penanganan perdagangan orang; 3) Menyebarluaskan komunikasi, informasi, dan edukasi (KIE) berkaitan pencegahan perdagangan orang; 4) Melakukan sosialisasi dan kampanye dalam upaya pencegahan tindak pidana perdagangan orang; 5) Mendorong terintegrasinya isu tindak pidana perdagangan orang ke dalam proses pembelajaran dalam pendidikan formal dan non-formal; 6) Memberikan pendidikan dan latihan kecakapan hidup bagi masyarakat; 7) Membangun mekanisme pengawasan dan perlindungan berbasis komunitas terhadap perdagangan orang; dan 8) Peningkatan kapasitas kelembagaan.

Upaya pencegahan dan penanganan perdagangan orang sebagaimana dimaksud pada pasal 6 di atas, selanjutnya dituangkan dalam Rencana Aksi Daerah Gugus Tugas Pencegahan. Untuk sub tugas bidang pencegahan dan partisipasi anak di Kabupaten Sambas tahun 2017 - 2020. Melalui Rencana aksi Daerah Gugus Tugas Pencegahan Human Trafficking (GTPHT) ini diharapkan mampu mengurangi terjadinya kasus perdagangan manusia di Kabupaten Sambas.

Berdasarkan data olahan BPPKB Kabupaten Sambas, kasus human trafficking yang terjadi di Kabupaten Sambas sejak tahun 2009 sampai September 2018 mengalami fluktuasi. Untuk lebih jelasnya, data korban human trafficking yang ditangani di Kabupaten Sambas dapat dilihat dari tabel berikut.

Tabel 1. Kasus Human Trafficking di Kabupaten

\begin{tabular}{|l|l|cccc|}
\hline NO & \multicolumn{1}{|c|}{ TAHUN } & \multicolumn{5}{c|}{ KORBAN } \\
& & ANAK & PEREMPUAN & LAKI-LAKI & JUMLAH \\
\hline 1 & 2009 & 11 & 2 & 0 & 13 \\
2 & 2010 & 3 & 3 & 0 & 6 \\
3 & 2011 & 13 & 4 & 0 & 17 \\
4 & 2012 & 4 & 2 & 10 & 16 \\
5 & 2013 & 3 & 10 & 5 & 18 \\
6 & 2014 & 6 & 5 & 28 & 39 \\
7 & 2015 & 1 & 12 & 3 & 16 \\
8 & 2016 & 15 & 0 & 0 & 15 \\
9 & 2017 & 0 & 2 & 1 & 3 \\
10 & 2018 & 0 & 2 & 0 & 2 \\
10 & JUMLAH & 56 & 42 & 47 & 145 \\
\hline
\end{tabular}

Sambas Tahun 2009-2018

JURNAL PENDIDIKAN DAN KONSELING VOLUME 3 NOMOR 2 TAHUN 2021
Sumber: Data olahan dari (Data Polres, Kejaksaan, PN, dan LBH Peka, RSUD Sambas, RSUD Pemangkat) (BPPKB Kab Sambas, 2018)

Kasus human trafficking ini mencapai angka tertinggi pada tahun 2014. Pada tahun-tahun berikutnya kasus ini justru mengalami penurunan, dan semakin berkurang hingga September 2018 ini yaitu hanya dua kasus. Kementerian Pemberdayaan Perempuan dan Perlindungan Anak merupakan salah satu kementerian yang fokus menangani masalah perdagangan orang. Terkait persoalan ini, diketahui kemenpppa memiliki beberapa program penanganan kasus perdagangan orang. Salah satunya adalah melakukan bimbingan konseling kepada korban traficking.

Berbeda dengan penelitian (Rider Daniel et al., 2017) yang fokus pada intervensi untuk melawan human trafficking melalui melawan factor penyebab masyarakat mudah untuk dijadikan obyek human trafficking. Penelitian ini fokus pada kajian penanganan human traficking dari sisi konselingnya. Dengan demikian penelitian ini bertujuan untuk mendeskripsikan 1) alur penanganan kasus human trafficking di Kemenpppa Kabupaten Sambas; 2) pelaksanaan bimbingan konseling terhadap korban kasus human trafficking di Kemenpppa Kabupaten Sambas; dan 3) hambatan penanganan kasus korban human trafficking di Kemenpppa Kabupaten Sambas.

\section{METODOLOGI PENELITIAN}

Prosedur penelitian ini menggunakan kualitatif dengan jenis penelitian analisis deskriptif. Menurut (Sugiyono, 2013) metode deskriptif adalah metode yang digunakan untuk menganalisis data dengan cara mendeskripsikan atau menggambarkan data yang telah terkumpul sebagaimana adanya. Penelitian ini dilakukan di Kemenpppa Kabupaten Sambas, Kalimantan Barat, Indonesia.

Peneliti menggunakan teknik wawancara untuk mengumpulkan data fokus penelitian. Wawancara ditujukan kepada informan dalam penelitian ini yaitu Ibu Nurazmi merupakan pegawai di Kemenpppa Kabupaten Sambas.

Data konseling human traficking di sambas yang sudah terkumpul direduksi sehingga tersisa data yang sesuai dengan tujuan penelitian. Setelah itu data didisplay berdasarkan kategori pokok masalah. Langkah berikutnya yaitu memverifikasi data dengan sumber data. Terkahir yaitu menarik kesimpulan akhir tentang alur penanganan; pelakasanaan bimbingan konseling; dan hambatannya. 


\section{HASIL PENELITIAN DAN PEMBAHASAN}

\section{Alur Penanganan Kasus di Kemenpppa Kabupaten Sambas}

Hasil penelitian (Rusyidi et al., 2017) program-program perlindungan anak korban trafficking menyediakan manfaat dalam berbagai bentuk. Perlindungan secara langsung diberikan kepada korban berupa untuk menghentikan viktimisasi korban, merehabilitasi korban untuk mengurangi dampak fisik, psikologis dan sosial yang dialami korban sehingga membantu korban untuk dapat berfungsi secara normal, dan mereintegrasikan korban ke dalam lingkungan asal dan lingkungan sosial yang lebih luas. Penghentian viktimisasi dilakukan dengan cara menjemput korban dari lokasi kejadian trafficking dan membawa korban ke tempat yang aman di mana ia mendapatkan bantuan dan perlindungan.

Program perlindungan terhadap korban human trafficking menurut hasil penelitian (Rusyidi et al., 2017) sejalan dengan alur penanganan untuk kasus human trafficking di Kemenpppa Kabupaten Sambas yaitu pencegahan, penanganan, pemulihan (Nurazmi, 2019). Alur pencegahan meliputi Penyuluhan kepada masyarakat, konseling, pembentukan peraturan perundang-undangan; 2) Alur Penanganan meliputi Pendampingan dan bantuan hukum, koordinasi dengan instansi terkait, pelayanan kesehatan; 3) Alur Pemulihan meliputi bimbingan mental spiritual, bimbingan fisik, bimbingan sosial.

\section{Gambaran Bimbingan Perseorangan terhadap Korban Human Trafficking}

Trafficking menimbulkan dampak yang signifikan terhadap kualitas hidup dan tumbuh kembang anak. DaSmpak tersebut timbul sebagai akumulasi kondisi dan perlakuan kekerasan serta eksploitasi yang dapat terjadi sejak tahap perekrutan, penampungan, pengiriman, dan atau penempatan. Anak yang diperdagangkan tercabut haknya untuk menerima pendidikan, bermain, bersosialisasi, serta terbebas dari tindak kekerasan. Mereka juga banyak mengalami gangguangangguan psikologis termasuk gangguan pasca trauma, depresi, dan sebagainya. Secara sosial, anak mengalami rasa malu yang luar biasa atau rasa bersalah yang terus menghantui karena menganggap dirinya tidak berarti, tidak berharga atau kotor (International Organization for Migration, 2012)

Dalam (Undang-Undang Nomor 23 Tahun 2002 Tentang Perlindungan Anak, 2002) mengatur secara khusus tugas negara dan masyarakat dalam perlindungan anak yang "bertujuan untuk menjamin terpenuhinya hak-hak anak agar dapat hidup, tumbuh, berkembang dan berpartisipasi secara optimal sesuai dengan harkat dan martabat kemanusiaan, serta mendapat perlindungan dari kekerasan dan diskriminasi, demi terwujudnya anak Indonesia yang berkualitas, berakhlak mulia dan sejahtera”. Sehingga anak korban trafficking berhak untuk mendapatkan perlindungan khusus dan pertolongan guna mengatasi berbagai dampak fisik, kesehatan dan psikologis yang dialaminya.

Dari hasil wawancara di Kemenpppa Kab. Sambas, bimbingan sosial perseorangan pada korban diberikan sesuai dengan kebutuhan korban perseorangan. Misalnya jika korban mengalami luka psikis, yang dilakukan oleh lembaga adalah menyediakan psikolog khusus yang sudah ahli di bidangnya untuk memulihkan kondisi dari korban. Jika korban tersebut mengalami luka fisik maka yang akan dilakukan oleh lembaga adalah memberikan perawatan medis kepada korban. Selanjutnya jika korban merupakan anak masa sekolah, maka korban tersebut akan diberikan fasilitas pendidikan. Dan ketika korban memerlukan pelatihan keterampilan, juga disediakan kelompok kerja, pemberian modal usaha, serta diikut sertakan pada balai latihan kerja sesuai dengan bakat yang dimiliki. Dan jika korban terlibat hukum dengan pelaku, maka korban dilindungi secara penuh dan dinas siap menyediakan pengacara untuk menyelesaikan kasus yang dihadapi. Kemenpppa kabupaten Sambas menyebut program ini dengan sebutan PULPUS yang merupakan program pembinaan. (Nurazmi, 2019)

Pemberian bimbingan kepada korban trafficking merupakan bentuk pembinaan atau pemulihan pada aspek mental yang diterapkan di Kemenpppa Sambas. Bimbingan mental langsung ditangani oleh psikolog. Jika di Kemenpppa melaksanakan bimbingan mental langsung ditangani oleh psikolog. Berbeda dengan di sekolah, korban trafficking ditangani oleh konselor sekolah (Satriani, 2013)

Berdasarkan paparan di atas, bimbingan perseorangan pada korban diberikan sesuai dengan kebutuhan korban perseorangan. Kemenpppa kabupaten Sambas menyebut program ini dengan sebutan PULPUS. Ada lima yang didapat oleh korban trafficking yaitu: 1) Korban luka psikis ditangani psikolog; 2) korban luka fisik maka dilakukan perawatan medis; 3) korban anak sekolah diberikan fasilitas pendidikan; 4) korban yang memerlukan pelatihan keterampilan di sediakan kelompok kerja, pemberian modal usaha, serta

JURNAL PENDIDIKAN DAN KONSELING VOLUME 3 NOMOR 2 TAHUN 2021 
diikut sertakan pada balai latihan kerja sesuai dengan bakat yang dimiliki; 5) korban terlibat hukum dengan pelaku, maka korban dilindungi secara penuh dan dinas siap menyediakan pengacara untuk menyelesaikan kasus yang dihadapi.

\section{Hambatan Penanganan Kasus Human Trafficking}

Beberapa kasus yang terjadi di Sambas, ternyata masih mengalami kendala dalam mengatasi bahkan memberantas tuntas pelaku human trafficking ini. Di antara hambatannya yaitu korban dan keluarga korban biasanya tidak menganggap apa yang dialami itu merupakan sebuah kejadian human trafficking. Mereka berpendapat bahwa, human trafficking itu adalah kasus yang benar-benar serius dalam arti menjual manusia dengan seutuhnya, maksudnya adalah persepsi mereka human trafficking ini adalah kasus menjual organ tubuh manusia dan lainnya. Padahal menurut undang-undang yang berlaku, bahwa gaji yang tidak sesuai dengan jam kerja pun disebut human trafficking. Inilah yang menjadi kendala dan bahkan menjadi bibit awal semakin berkembangnya kasus ini (Nurazmi, 2019) Ada juga kasus korban yang telah dibina dan direhabilitasi yang diberikan modal usaha untuk membuka usaha sendiri di daerahnya. Dan faktanya, modal tersebut disalahgunakan korban sehingga pada akhirnya kembali menjadi korban human trafficking dengan alasan kurangnya modal dan pemenuhan kebutuhan serta konsumtif dari korban itu sendiri (Nurazmi, 2019).

Dalam praktiknya, banyak sekali hambatan dalam mendampingi korban trafficking atau keluarganya. Hambatan tidak hanya dari korban dan keluarga tapi juga dari aparat penegak hukum.

\section{DAFTAR PUSTAKA}

BPPKB Kab Sambas. (2018). Data Kasus Human Trafficking di Kabupaten Sambas Tahun 2009-2018.

International Organization for Migration. (2012). Trafficking in Indonesia: Severity dan Victim Profile. IOM-Indonesia.

Kemenpppa. (2018). Pencegahan dan Penanganan Tindak Pidana Perdagangan Orang. Kemenpppa.Go.Id.

https://www.kemenpppa.go.id/lib/uploads/lis t/f3b9b-buku-laptah-2018.pdf

Nurazmi. (2019). Wawancara dengan Informan Staf Kemenpppa Kabupaten Sambas.

Undang-undang Nomor 23 Tahun 2002 Tentang Perlindungan Anak, Pub. L. No. 23 Tahun 2002, 1 (2002). https://jdihn.go.id/files/4/2002uu023.pdf

Rusyidi, B., Nuriyah, E., \& Meilani, L. (2017).
Keluarga sering enggan menceritakan masalahnya dengan berbagai alasan. Ketakutan terhadap oknum-oknum tertentu sebagai sebuah sindikat perdagangan (Wulandari \& Wicaksono, 2014)

\section{SIMPULAN}

Adapun alur penanganan korban trafficking di Kemenpppa yaitu 1) Pencegahan (Penyuluhan kepada masyarakat, konseling, pembentukan peraturan perundang-undangan); 2) Penanganan (Pendampingan dan bantuan hukum, koordinasi dengan instansi terkait, pelayanan kesehatan); 3) Pemulihan (Bimbingan mental spiritual, bimbingan fisik, bimbingan sosial).

Bimbingan perseorangan pada korban diberikan sesuai dengan kebutuhan korban perseorangan. Kemenpppa kabupaten Sambas menyebut program ini dengan sebutan PULPUS. Ada lima yang didapat oleh korban trafficking yaitu: 1) Korban luka psikis ditangani psikolog; 2) korban luka fisik maka dilakukan perawatan medis; 3) korban anak sekolah diberikan fasilitas pendidikan; 4) korban yang memerlukan pelatihan keterampilan di sediakan kelompok kerja, pemberian modal usaha, serta diikut sertakan pada balai latihan kerja sesuai dengan bakat yang dimiliki; 5) korban terlibat hukum dengan pelaku, maka korban dilindungi secara penuh dan dinas siap menyediakan pengacara untuk menyelesaikan kasus yang dihadapi. Hambatan terjadi karena korban dan keluarga korban biasanya tidak menganggap apa yang dialami itu merupakan sebuah kejadian human trafficking; dan ada penerima modal usaha yang tidak menggunakan modal sesuai tujuan.

KEBIJAKAN PERLINDUNGAN SOSIAL DAN PENCEGAHAN RETRAFFICKING BAGI ANAK DI PROVINSI JAWA BARAT. Prosiding Penelitian Dan Pengabdian Kepada Masyarakat, 4(1), 140. https://doi.org/10.24198/jppm.v4i1.14223

Peraturan Daerah Kabupaten Sambas No. 3 Tahun 2015 tentang Pencegahan dan Penanganan Perdagangan Orang, (2015).

Satriani, R. A. (2013). Studi Tentang Perdagangan Manusia (Human Trafficking) Pada Remaja Putri Jenjang Sekolah Menengah Di Kota Surabaya. Jurnal BK UNESA, 4(1). https://ejournal.unesa.ac.id/Index.Php/Jurnal -Bk-Unesa/Article/View/6121

Sugiyono. (2013). Metode Penelitian Kuantitatif, kualitatif dan $R \& D$. AlfabetaCV.

Wulandari, C., \& Wicaksono, S. S. (2014). Tindak Pidana Perdagangan Orang (Human Trafficking) Khususnya Terhadap 
Perempuan Dan Anak: Suatu Permasalahan

Dan Penanganannya Di Kota Semarang. Jurnal https://jurnal.uns.ac.id/yustisia/article/downl oad/29272/20094 